\title{
Microbial Loads of Ogiri-Ahuekere Condiment Produced from Groundnut Seed (Arachis hypogaea Linn)
}

\author{
Chukwu, M. $\mathbf{N}^{1 \rtimes}$ \\ Ezeagwula, C. G. ${ }^{2}$ (iD \\ Nwakaudu, A. A $^{3}$ \\ Oti, W. ${ }^{4}$ \\ Anyaogu, I5
}

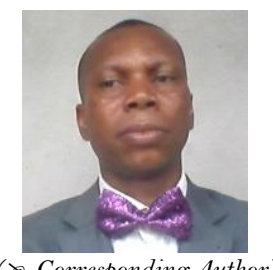

( Corresponding Author)

'Department of Food Technology, Abia State Polytechnic, Aba, Abia State, Nigeria. Email:mchukwu61@gmail.com Tel:+2348184516106

${ }^{2}$ Department of Microbiology, Abia State Polytechnic, Aba, Abia State, Nigeria.

Email: ezeagwulaco@gmail.com Tel: +2348052691319

${ }^{\top}$ Department of Food Science and Technology, Federal University of Technology, Owerri, Imo State, Nigeria. Email:angelanwakaudu4@gmail.com Tel: +2348038979955

'Department of Biochemistry, Abia State Polytechnic, Aba, Abia State, Nigeria.

Email:williamsoti4real@gmail.com Tel: +2348185436532

${ }^{5}$ Department of Hospitality and Hotel Management, Abia State Polytechnic, Aba, Abia State, Nigeria.

Email:anyaogupm@yahoo.co.uk Tel: +2348068808901

\section{Abstract}

Microbial loads of ogiri-ahuekere condiment produced from groundnut seeds were examined. The groundnut seeds were sun-dried for 8 hours, dehulled and boiled for 8 hours using kerosene stove. The cooked cotyledons were milled manually into a paste and wrapped in small portions $(30 \mathrm{~g})$ with blanched plantain leaves. The wrapped samples were fermented in a container for 1-10 day(s) while the unfermented cooked groundnut paste was used as a control. The freshly prepared samples of ogiri-ahuekere were used for microbial analysis and this action was carried out under sterile aseptic conditions. Statistical analysis of the data was carried out using ANOVA method with application of SPSS version 20. The significant difference between the mean values was determined by Tukey's test at $95 \%$ level of confidence. There was no growth in unfermented sample for TCC and TFMC while there was growth for TBC. There was significant increases in TCC which ranged from $0.67-6.47 \times 10^{7} \mathrm{cfu} / \mathrm{g}$, TBC $\left(0.83-8.60 \times 10^{7} \mathrm{cfu} / \mathrm{g}\right)$ and TFMC $(0.30-$ $\left.4.90 \times 10^{7} \mathrm{cfu} / \mathrm{g}\right)$. The results obtained from the study have shown the prevalence of bacteria throughout the period of fermentation in an increasing population.

Keywords: Fermentation, Coliform count, Bacterial count, Fungal count, Colony, Paste.

Citation | Chukwu, M.N; Ezeagwula, C.G.; Nwakaudu, A.A; Oti, W.; Anyaogu, I (2019). Microbial Loads of Ogiri-Ahuekere Condiment Produced from Groundnut Seed (Arachis hypogaea Linn). Agriculture and Food Sciences Research, 6(1): 114-119. History:

Received: 7 March 2019

Revised: 5 April 2019

Accepted: 10 May 2019

Published: 4. July 2019

Licensed: This work is licensed under a Creative Commons Attribution 3.0 License $($ (c) $)$ Er

Publisher: Asian Online Journal Publishing Group
Contribution/Acknowledgement: All authors contributed to the conception and design of the study.

Funding: This study received no specific financial support.

Competing Interests: The authors declare that they have no conflict of interests.

Transparency: The authors confirm that the manuscript is an honest, accurate, and transparent account of the study was reported; that no vital features of the study have been omitted; and that any discrepancies from the study as planned have been explained.

Ethical: This study follows all ethical practices during writing.

\section{Contents}

1. Introduction

References 


\section{Contribution of this paper to the literature}

The study of the microbial loads of ogiri-ahuekere condiment showed the contamination of the condiment as well as the number of cells of different microbial counts. Ogiri-ahuekere condiment will compete favourably in the market if processed or handled under sanitary conditions.

\section{Introduction}

The scientific classification of groundnut as kingdom (plantae), order (fabales), family (fabaleae), sub-family (faboideae), tribe (aeschynomenae), genus (arachis) and specie (hypogaea) [1]. Groundnut (Arachis hypogeae Linn) is an important oil crop of Brazil origin. It is specie in the legumes or "bean" family (Fabaceae). It is also widely produced in Guinea Savannah ecological zone of Nigeria. It is cultivated in tropical and warm temperate climate [2]. Groundnut is an important oil crop of Brazilian origin, cultivated in tropical and warm temperate climates. The crop is grown usually as a component of a variety of crop mixtures including sorghum, millet, cowpea and maize [3].

Sahayaraj and Martin [4] reported that groundnut is an important oil seed and cash crop accounting for more than one third $(1 / 3)$ of the total oil seeds in India. Beside income for farmers, it provides an inexpensive source of high quality dietary protein and oil [5]. Groundnuts are particularly susceptible to contamination during growth and storage. Poor storage of groundnut can lead to an infection by the mould fungus Aspergillus flavus, releasing the toxic and highly carcinogenic substance called aflatoxin. The aflatoxin producing mould exists throughout the groundnut growing areas and may produce aflatoxin in the groundnuts when the conditions are favorable to fungal growth [6].

Condiments are edible substances which are added to impart a particular flavor, enhance its flavor, and in some cultures to complement the dish. Many condiments are packaged in single-sachets/packets e.g. mustard and ketchup. They are prepared from both plant and animal materials using processes in which micro-organisms play active roles in the physical, nutritional and sensory modification of the starting materials. The local condiment is an oily paste with strong putrid ammonical odor made from fermented vegetable protein [7]. Condiments are prepared by traditional methods of uncontrolled solid substrate fermentation resulting in extensive hydrolysis of the protein and carbohydrate components. Condiments are used as soup condiments and they generally have strong aroma [8].

Condiments are excellent sources of proteins with essential amino acids, and also contain lipids, carbohydrates, essential fatty acids and vitamins [9]. Many families in West Africa often used fermented condiments as low cost meat substitute. Fermented condiments improve nutritive values of foods as well as sensory properties as taste enhancers; contain antioxidants and neutraceuticals that promote health [10].

Fermented condiments often have a stigma attached to them as they are considered to be food for the poor [11]. Traditional diets in Nigeria often lack variety and consist of large quantities of the staple foods (cassava, yam, maize) with supplements of plantain, cocoyam, rice and beans depending on their availability and seasons [12]. Soups eaten with the staples are essential components of the diet and may contain a variety of seeds, nuts, pulses and leaves [13].

Fermentation is one of the oldest and most economical methods of producing and preserving foods in developing countries [14]. Fermentation remains of interest since they do not require refrigeration during distribution and storage [15]. Apart from increasing the shelf life, and a reduction in the anti-nutritional factors, fermentation markedly improves the digestibility, nutritive value and flavour of the raw seeds [16]. When fermentation is involved in food processing, microorganisms are present. Fermentation is an energy yielding metabolic process which involves the decomposition of substrate in the anaerobic condition. Members of the fermenting organisms are important; for example, Bacillus spp in ogiri preparation [1,2].

Fagbemi, et al. [17] described fermentation of condiments as a multi-step process which does not include a formal inoculation step. Bacteria required for the fermentation appear to be incidental to both the raw and processed materials. Indigenous flora is likely carried over from fermentation to fermentation sieves, trays and bags which are respectively used in condiment production. Contamination of spores from the local environment may also contribute to the fermentation micro flora. It is likely that fermentation begins when the cooled, softened, dehulled oil seeds are packaged with leaves or other materials [18]. Changes over the course of 6 days of fermentation period include a $\mathrm{pH}$ decrease for the first four days and an increase thereafter [17].

Achi [14] reviewed some important microorganisms found in fermented condiments after different periods of fermentation at optimum conditions. Ogbonna, et al. [19] determined the optimum $\mathrm{pH}$ for the growth of these bacteria as 7.5 while the optimum temperature is $33-40^{\circ} \mathrm{C}$ for 3 days. The methods employed in the manufacture of fermented condiment differ from one region to another because these processes are based on traditional systems. According to local custom, climate conditions and the type of substrates used, specific process variation occur [8]. In general, fermentation takes place under conditions which the producers have found to be favorable for appropriate growth and activity of microorganisms.

This work is aimed at determining the microbial loads of ogiri-ahuekere condiment produced from groundnut seed using natural fermentation method. The production of ogiri-ahuekere will give value addition to groundnut and as source of income to both the farmers and the producers. This also could help in determining the sanitary condition of the condiment in the market.

\section{Materials and Methods}

\subsection{Collection of Materials}

The groundnuts seeds were bought from a local market at Aba, Abia State, Nigeria. Other materials such as swab sticks, syringes, Whatman filter papers No 1, foil, cotton wool, hand gloves, cover lips, distilled water and media produced by Titan Biotech Ltd and Micro-master Ltd, India were purchased from Rufus Chemicals, Aba. Other utensils used were produced by Search tech Ltd, India and they include glass wares, pots, furnace, desiccators, plates, autoclave, DHP 9032 incubators, Bunsen burner, Olympus microscope and colony counter. The reagents used were of analytical grade and they include iodine solution, ethanol, Safaranin solution, sulphuric acid, 
methylene blue, starch, glucose, lactose, sucrose, fructose, maltose, boric acid, sodium hydroxide, bromocresol green and methyl red, EDTA, petroleum ether etc. Reagents were produced by BDH Chemicals Ltd, Poole England.

\subsection{Production of Ogiri-Ahuekere from Raw Groundnut Seeds}

Five hundred grams $(500 \mathrm{~g})$ groundnut seeds were weighed and spread under the sun for easy removal of the seed coats (hulls). The hulls were removed by rubbing the seeds in-between the palms in accordance with the method described by Chukwu, et al. [1]. The preparation of ogiri-ahuekere was prepared according to Chukwu, et al. [1];Chukwu, et al. [2]. Figure 1 shows the flow diagram for the production of ogiri-ahuekere.

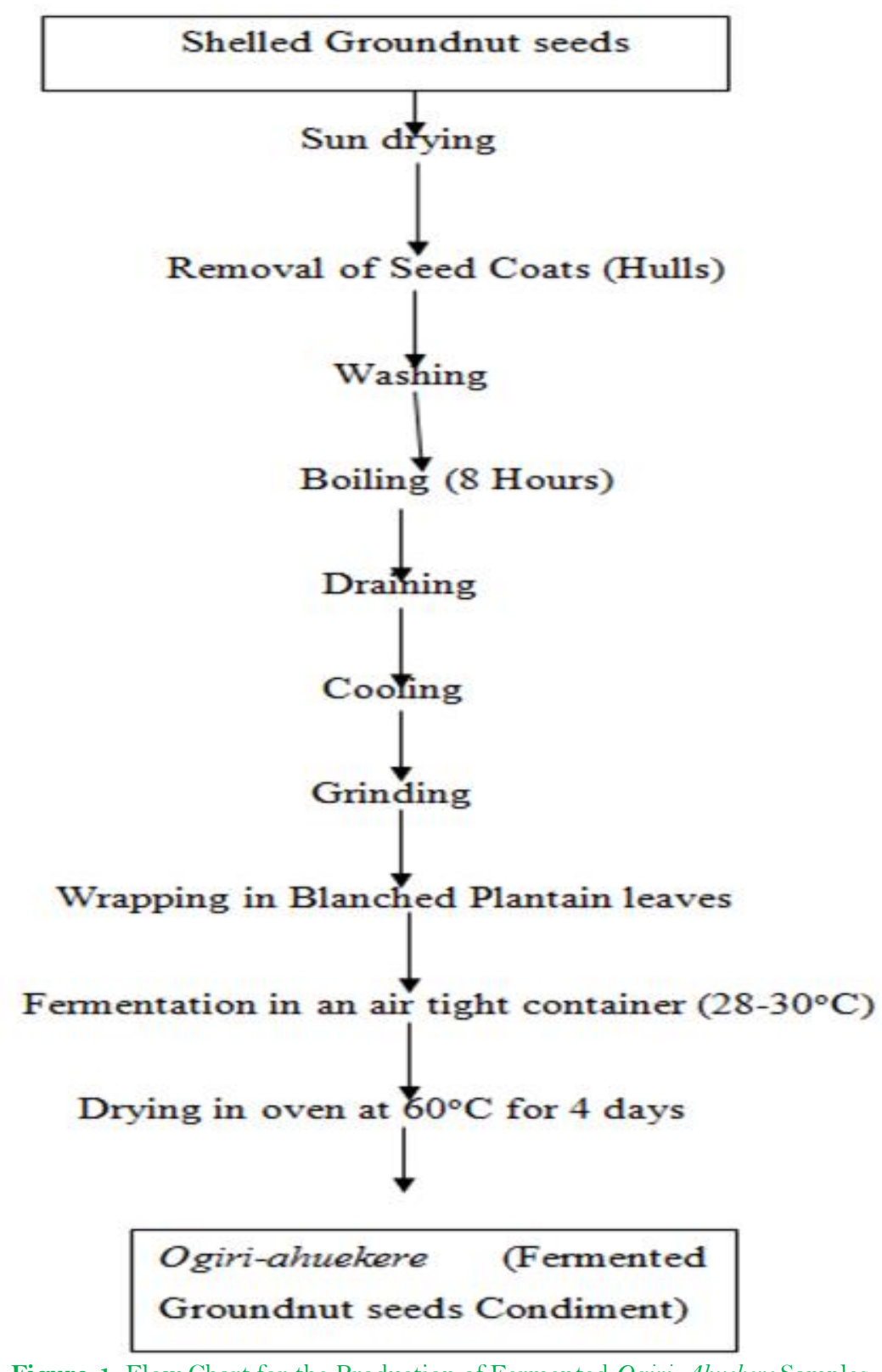

Figure-1. Flow Chart for the Production of Fermented Ogiri-Ahuekere Samples. Source: Chukwu, et al. [8].

\subsection{Microbial Analysis of Ogiri-Ahuekere}

Freshly fermented samples of ogiri-ahuekere were used for microbial analysis

\subsection{Media Preparation}

The media used were nutrient agar (NA), Salmonella-Shigella agar (SSA), MacConkey agar (MA), mannitol agar, blood agar (BA) and potato-dextrose agar (PDA). PDA was used for fungi isolation while all the other agars were used for bacterial isolations. These agars were prepared as follows: $2.8 \mathrm{~g}$ of nutrient agar was dissolved in $100 \mathrm{ml}$ of water; $11.1 \mathrm{~g}$ of mannitol was dissolved in $100 \mathrm{ml}$ of water; $5.2 \mathrm{~g}$ of MacConkey agar was dissolved in $100 \mathrm{ml}$ of water; $6.3 \mathrm{~g}$ of SSA was dissolved in $100 \mathrm{ml}$ of water; $2.8 \mathrm{~g}$ of nutrient agar was dissolved in $2 \mathrm{ml}$ of blood to form the blood agar; and potato extract was made up to $100 \mathrm{ml}$ mark with distilled water. These agars were sterilized in the autoclave at $121^{\circ} \mathrm{C} / 15$ psi for 15 minutes. The media were poured into sterile petri dishes on gelling. These were done in triplicates.

\subsection{Serial Dilution}

Nine folds serial dilutions were made using 10 test tubes placed on a test tube rack. One gram of the test sample was dissolved in $9 \mathrm{ml}$ of normal saline and diluents in a test tube and the content was thoroughly shaken. Subsequent serial dilutions $\left(10^{-2}, 10^{-3}, 10^{-4}, 10^{-5}, 10^{-6}\right)$ were made from the solution by adding serially $1 \mathrm{ml}$ of the sample solution from proceeding concentration to $9 \mathrm{ml}$ of the diluents using sterile syringe. After dilution, $0.1 \mathrm{ml}$ of $10^{-5}$ dilution ( $10^{5}$ tubes) was picked out and dropped into different plates of nutrient agar, MacConkey agar, Salmonella-Shigella agar, mannitol agar, and blood agar for bacteria isolation and potato-dextrose agar for fungi 
isolation. Both pour plate and streak plate methods were employed. The plates were incubated for 24 hours at $37^{\circ} \mathrm{C}$. Plates were examined and the colony growths were counted [20].

\subsection{Determination of Microbial Loads of Ogiri-Ahuekere Samples}

The method of the ICMSF [21] was employed. One gram (1g) of the prepared sample was dissolved in $9 \mathrm{ml}$ sterile distilled water (diluents) and mixed vigorously by shaking. About $1 \mathrm{ml}$ of the resultant mixture was aseptically transferred to $9 \mathrm{ml}$ sterile water in the test tube and thoroughly mixed. This action was carried out under sterile aseptic conditions. The dilution was continued serially until the sixth dilution was attained. The potato dextrose agar culture plates were incubated at room temperature for two days ( 48 hours) while the nutrient agar culture plates were incubated at $37^{\circ} \mathrm{C}$ for 24 hours in the incubator. All the plates were observed daily. The number of colonies formed in each culture plate at the end of incubation period was counted using the Gallenkamp electronic colony method [21]. The total bacterial count was determined by counting the number of viable cells on nutrient agar for bacteria and potato dextrose for fungi plates respectively. Thereafter, the number of viable cells was counted by using model TT201 Colony counter. Total coliform count was determined by introducing the sample inoculums in Eosin methylene blue agar using pour plate method. The plates were incubated aerobically for $18-24$ hours at $57^{\circ} \mathrm{C}$. The total viable cells from primary plates were calculated using model TT201 Colony Counter. Thereafter, a standard formula was used to calculate the number of the total coliform count [22]. The total microbial counts (cfu per gram) of food sample were calculated according to Equation 1.

$$
\begin{aligned}
& T M C=\frac{\text { Number of colonies observed } \times \text { inoculum plated }}{\text { Weight of inoculum } \times \text { dilution factor }} \\
& T M C=\frac{\text { Total viable cells } \times \text { inoculum plated }}{\text { Weight of inoculum } \times \text { dilution factor }}-
\end{aligned}
$$

\section{Results and Discussion}

Table 1 showed the average total microbial counts of ogiri-ahuekere produced from groundnut seeds at various fermentation time. The microbial counts included total coliform count, total bacteria count and total fungi/mould count, no growth in the unfermented ahuekere sample.

\subsection{Total Coliform Count (TCC)}

The TCC of unfermented ahuekere $(0.00)$ was not significantly $(\mathrm{p} \leq 0.05)$ different from TCC of fermented ogiriahuekere sample from 1 day fermentation $\left(0.67 \times 10^{7} \mathrm{cfu} / \mathrm{g}\right)$. Table showed that TCC of fermented ogiri-ahuekere samples from 1 and 2 day(s) were significantly the same while TCC of 2 days fermented ogiri-ahuekere sample $\left(1.03 \times 10^{7} \mathrm{cfu} / \mathrm{g}\right)$ was significantly different from TCC of unfermented ahuekere though similar to TCC $\left(1.60 \times 10^{7} \mathrm{cfu} / \mathrm{g}\right)$ of 3 days fermented ogiri-ahuekere sample. It was observed that the TCC $\left(2.43 \times 10^{7} \mathrm{cfu} / \mathrm{g}\right)$ of 5 days fermented ogiri-ahuekere sample was not significantly different from the TCC of 3, 4 and 6 days fermented ogiriahuekere samples $\left(1.60,1.93\right.$, and $3.20 \times 10^{7} \mathrm{cfu} / \mathrm{g}$ respectively) while the TCC of 6 days fermented ogiri-ahuekere sample was significantly different of that of 4 days fermented ogiri-ahuekere sample. The total coliform count of 8 days fermented ogiri-ahuekere sample was $4.67 \times 10^{7} \mathrm{cfu} / \mathrm{g}$. The total coliform count (TCC) of 8 days fermented ogiriahuekere sample was significantly different from TCC of 6 and 9 days $\left(5.70 \times 10^{7} \mathrm{cfu} / \mathrm{g}\right)$ fermented ogiri-ahuekere samples, and it was also the same with TCC of 7 days fermented ogiri-ahuekere sample $\left(3.87 \times 10^{7} \mathrm{cfu} / \mathrm{g}\right)$; although, TCC of 6 and 7 days fermentation were significantly the same. However, the TCC of 9 and 10 days fermented ogiriahuekere samples were the same statistically but significantly different from the TCC from other samples. The table also illustrated how the total coliform count increased with the fermentation day [23].

\subsection{Total Bacteria Count (TBC)}

There was also significant increase in the $\mathrm{TBC}$ with respect to the days of fermentation. The unfermented ahuekere sample had TBC $\left(0.83 \times 10^{7} \mathrm{cfu} / \mathrm{g}\right)$ which was statistically the same with the TBC from 1 day fermented ogiri-ahuekere sample. The TBC $\left(1.37,1.70\right.$ and $2.33 \times 10^{7} \mathrm{cfu} / \mathrm{g}$ respectively) from samples fermented for 1,2 and 3 days were significantly $(\mathrm{p} \leq 0.05)$ similar but were significantly different from the TBC $\left(2.80 \times 10^{7} \mathrm{cfu} / \mathrm{g}\right)$ of 4 days fermented ogiri-ahuekere sample. It was observed that after 4 days fermentation, the TBC of the samples increased significantly throughout the period of fermentation Table 1

The TBC of 5 days fermented ogiri-ahuekere sample was $3.47 \times 10^{7} \mathrm{cfu} / \mathrm{g}$ which is significantly different from the $\mathrm{TBC}\left(4.40 \times 10^{7} \mathrm{cfu} / \mathrm{g}\right)$ of 6 days ogiri-ahuekere samples. There were significant difference among the TBC of 5 , $6,7,8,9$ and 10 days ogiri-ahuekere samples. This significant increase in TBC was due to the increase in fermentation time and similar results were reported by Peter-Ikechukwu, et al. [24].

\subsection{Total Fungi/Mould Counts (TFMC)}

Total Fungi/Mould Counts (TFMC) was also shown in Table 1. The TFMC of all the ogiri-ahuekere samples increased significantly with increase in fermentation time. The unfermented ahuekere had no fungi growth. The following samples were statistically similar in TFMC: unfermented, 1 and 2 day(s) samples (0.00, 0.30 and $0.60 \times 10^{7} \mathrm{cfu} / \mathrm{g}$ respectively); 3 and 4 days samples $\left(1.00\right.$ and $1.33 \times 10^{7} \mathrm{cfu} / \mathrm{g}$ respectively); 6 and 7 days samples (2.73 and $3.23 \times 10^{7} \mathrm{cfu} / \mathrm{g}$ respectively); and 7 and $8\left(3.23\right.$ and $3.33 \times 10^{7} \mathrm{cfu} / \mathrm{g}$ respectively) days fermented samples respectively. However, the TFMC $\left(2.03,4.33\right.$ and $4.90 \times 10^{7} \mathrm{cfu} / \mathrm{g}$ respectively) from samples fermented for 5,9 and 10 days were significantly $(\mathrm{p} \leq 0.05)$ different from TFMC of the rest of the samples. Sanni, et al. [25] and reported that some Nigerian soup condiments have the microbial load within the range of $10^{7}$ and $10^{9} \mathrm{cfu} / \mathrm{g}$ as well as PeterIkechukwu, et al. [23]. 
Table-1. Mean Microbial Count of Ogiri-Ahuekere Fermented for 0-10 Days.

\begin{tabular}{|c|c|c|c|}
\hline \multirow[b]{2}{*}{ Fermentation time (day) } & \multicolumn{3}{|c|}{ Total Count $\left(\times 10^{7} \mathrm{cfu} / \mathrm{g}\right)$} \\
\hline & TCC & TBC & TFMC \\
\hline 0 & $0.00^{\mathrm{a}}$ & $0.83^{\mathrm{a}}$ & $0.00^{\mathrm{a}}$ \\
\hline 1 & $0.67^{\mathrm{ab}}$ & $1.37^{\mathrm{ab}}$ & $0.30^{\mathrm{a}}$ \\
\hline 2 & $1.03^{\mathrm{bc}}$ & $1.7 \mathrm{O}^{\mathrm{bc}}$ & $0.60^{\mathrm{ab}}$ \\
\hline 3 & $1.60^{\mathrm{cd}}$ & $2.33^{\mathrm{cd}}$ & $1.00^{\mathrm{bc}}$ \\
\hline 4 & $1.93^{\mathrm{d}}$ & $2.80^{\mathrm{de}}$ & $1.33^{\mathrm{c}}$ \\
\hline 5 & $2.43^{\mathrm{de}}$ & $3.47^{\mathrm{e}}$ & $2.03^{\mathrm{d}}$ \\
\hline 6 & $3.20^{\mathrm{ef}}$ & $4.4 \mathrm{O}^{\mathrm{f}}$ & $2.73^{\mathrm{e}}$ \\
\hline 7 & $3.87^{\mathrm{fg}}$ & $5.50^{g}$ & $3.23^{\mathrm{ef}}$ \\
\hline 8 & $4.67^{\mathrm{g}}$ & $6.50^{\mathrm{h}}$ & $3.33^{\mathrm{f}}$ \\
\hline 9 & $5.7 \mathrm{O}^{\mathrm{h}}$ & $7.30^{\mathrm{i}}$ & $4.33^{\mathrm{g}}$ \\
\hline 10 & $6.47^{\mathrm{h}}$ & $8.60^{j}$ & $4.90^{\mathrm{h}}$ \\
\hline LSD & 1.014 & 0.843 & 0.531 \\
\hline
\end{tabular}

Note: Means with the same superscripts are statistically the same but means with the different superscripts are significantly different from each other $(\mathrm{p} \geq 0.05)$ in the column. Where

$\mathrm{TCC}=$ Total Coliform Counts

TBC $=$ Total Bacteria Counts

TFMC $=$ Total Fungi/Mould Counts

Note: The microbial load increased significantly from 2-10 days fermentation of groundnut

seeds.

\section{Conclusion}

The results obtained from the study have shown the prevalence of bacteria throughout the period of fermentation in an increasing population. Total counts of the microorganisms involved in fermentation process showed that contamination might have occurred either from processing equipment, the handlers or from the raw materials and the environment. Fermentation time caused significant increase in the microbial loads of ogiriahuekere samples

\section{Recommendation}

Fermented groundnut condiments could improve nutritive values of foods as well as sensory properties as taste enhancers; contain antioxidants and neutraceuticals that promote health; however it is recommended that further study on the toxicology of this product be carried out before it can wholly be accepted for human consumption.

\section{References}

[1] M. N. Chukwu, C. S. Nwakodo, Q. Alozie, and J. C. Ndulaka, "Comparative studies on organoleptic properties of ogiri-ahuekere and ogiri-egusi condiments," Journal of Food Science Research Quality Control, vol. 4, pp. 11-19, $2018 \mathrm{a}$.

[2] M. N. Chukwu, C. S. Nwakodo, J. C. Ndulaka, and N. J. Nwokocha, "Production and proximate composition of ogiri-ahuekere (Arachis hypogaea Linn) seed condiment," Research Journal of Agricultural and Environmental Management, vol. 7, pp. 007-017, 2018 b.

[3] C. Monago, P. Ogbomeh, and P. Joshua, "Effect of African oil bean seed (Pentaclethra macrophylla) on blood cholesterol level in rats," Global Journal of Pure and Applied Sciences, vol. 10, pp. 165-168, 2004. Available at: rats, Global Journal of Pure and Applied Sciences,
https://doi.org/10.4314/gjpas.v10i1.16376.

[4] K. Sahayaraj and P. Martin, "Assessment of Rhynocoris marginatus (Fab.)(Hemiptera: Reduviidae) as augmented control in groundnut pests," Journal of Central European Agriculture, vol. 4, pp. 103-1 10, 2003.

[5] J. Butterwort and X. Wu, "China, peoples republic of oil seeds and products," A Chinas Peanut Sector USDA Foreign Agricultural Service Report2004.

[6] C. W. Nevius, "Effect of dietary substitution of groundnut oil on blood glucose, lipid profile and redox status in streptozotocindiabetic rats," The Yale Journal of Biology and Medicine, vol. 79, pp. 9-17, 2003.

[7] B. Omafuvbe, S. Abiose, and O. Shonukan, "Fermentation of soybean (Glycine max) for soy-daddawa production by starter cultures of bacillus," Food Microbiology, vol. 19, pp. 561-566, 2002.

[8] M. N. Chukwu, N. O. Kabuo, E. U. Onyeka, T. C. Odom, O. Nwogu, N. J. Nwokocha, and J. C. Ndulaka, "Production and organoleptic attributes of ogiri-ahuekere produced from groundnut (Arachis hypogaea Linn) seeds," Journal of Food Science Research Quality Control, vol. 3, pp. 63-72, 2017.

[9] L. Ouoba, K. Rechinger, V. Barkholt, B. Diawara, A. Traore, and M. Jakobsen, "Degradation of proteins during the fermentation of African locust bean (Parkia biglobosa) by strains of Bacillus subtilis and Bacillus pumilus for production of Soumbala," Journal of Applied Microbiology, vol. 94, pp. 396-402, 2003. Available at: https://doi.org/10.1046/j.1365-2672.2003.01845.x.

[10] A. E.-G. A. Yagoub, B. E. Mohamed, A. H. R. Ahmed, and A. H. El Tinay, "Study on Furundu, a traditional Sudanese fermented Roselle (Hibiscus sabdariffa L.) seed: effect on in vitro protein digestibility, chemical composition, and functional properties of the total proteins," Journal of Agricultural and Food Chemistry, vol. 52, pp. 6143-6150, 2004. Available at: https://doi.org/10.1021/jfo496548.

[11] C. Ogueke, J. Nwosu, C. Owuamanam, and J. Iwouno, "Ugba, the fermented African Oilbean Seeds; its production, chemical composition, preservation, safety and health benefits," Pakistan Journal of Biological Sciences, vol. 13, pp. 489-496, 2010. Available at: https://doi.org/10.3923/pjbs.2010.489.496

[12] H. Sitren, E. Ahmed, and D. George, "In vivo and in vitro assessment of antinutritional factors in peanut and soy," Journal of Food Science, vol. 50, pp. 418-423, 1985. Available at: https://doi.org/10.1111/j.1365-2621.1985.tb13416.x.

[13] O. Chukwu, B. Orhevba, and B. I. Mahmood, "Influence of hydrothermal treatments on proximate compositions of fermented locust bean (dawadawa)," Journal of Food Technology, vol. 8, pp. 99-101, 2010. Available at: https://doi.org/10.3923/jftech.2010.99.101.

[14] O. Achi, "The potential for upgrading traditional fermented foods through biotechnology," African Journal of Biotechnology, vol. 4, pp. 375-380, 2005.

[15] O. M. David and E. Y. Aderibigbe, "Microbiology and proximate composition of ogiri, a pastry produced from different melon seeds," New York Science Journal, vol. 3, pp. 18-27, 2010.

[16] K. Dajanta, A. Apichartsrangkoon, and E. Chukeatirote, "Antioxidant properties and total phenolics of Thua Nao (a Thai fermented soybean) as affected by bacillus-fermentation," Journal Microbial Biochem Technol, vol. 3, pp. 56-59, 2011. Available at: https://doi.org/10.4172/1948-5948.1000052.

[17] T. N. F. Fagbemi, A. F. Eleyemi, H. N. Atum, and O. Akpambang, "Nutritional composition of fermented fluted pumpkin (Telfairia occidentalis) seeds for production of ogiri-ugu," in Fermented Foods and Beverages. IFT General Annual Meeting, New Orleans, Louisiana, 2005. 
[18] S. Giami and L. Barber, "Utilization of protein concentrates from ungerminated and germinated fluted pumpkin (Telfairia occidentalis Hook) seeds in cookie formulations," Journal of the Science of Food and Agriculture, vol. 84, pp. 1901-1907, 2004. Available at: https://doi.org/10.1002/jsfa.1881.

[19] D. Ogbonna, T. Sokari, and S. Achinewhu, "Development of an owoh-type product from African yam beans (Sphenostylis stenocarpa)(Hoechst (ex. A. Rich.) Harms.) seeds by solid substrate fermentation," Plant Foods for Human Nutrition, vol. 56, pp. 183-194, 2001.

[20] V. N. Enujiugha, "Major fermentative organisms in some Nigerian soup condiments," Pakistan Journal of Nutrition, vol. 8, pp. 279283, 2009. Available at: https://doi.org/10.3923/pjn.2009.279.283.

[21] ICMSF, Microbial ecology of foods. International commission on microbiological specification for foods vol. 2. London: Academic Press, 1978.

[22] M. Chessbrough, Medical laboratory manual vol. 2. London: Cambridge University Press, 2006.

[23] A. Peter-Ikechukwu, N. Kabuo, and S. Alagbaoso, "Effect of wrapping materials on physic-chemical and microbiological qualities of fermented melon seed (Citrullus colocynthis L) used as condiment," American Journal of Food Science and Technology, vol. 4, pp. 14$19,2016$.

[24] I. A. Peter-Ikechukwu, I. Olawuni, O. C. C., N. E. Odimegwu, E. A. Uzoukwu, and C. Eluchie, "Effect of wrapping material on chemical and microbiological qualities of fermented melon seed (Citrullus vulgaris L. Series)," Analytical Chemistry, vol. 15, pp. 074082, 2015.

[25] A. Sanni, G. Ayernor, E. Sakyi-Dawson, and S. Sefa-Dedeh, "Aerobic spore-forming bacteria and chemical composition of some Nigerian fermented soup condiments," Plant Foods for Human Nutrition, vol. 55, pp. 111-118, 2000. 